\title{
Through a Glass, Intimately: The Distant Closeness of Paula Fox's One-Eyed Cat
}

\section{by Perry Nodelman}

As its title suggests, Paula Fox's One-Eyed Cat is about seeing, and about being seen. It is also about understanding what one sees, and most significantly, about what it means to be seen by other people. Above all, then, it is a book about insight, and about being subject to the insights of other people.

The cat of the title may have lost its missing eye to cold weather, or in a fight with another animal. But young Ned believes he is himself responsible; since his father does not want him to use the gun he has received as a birthday gift from his uncle Hilary, he has sneaked out of the house with it in the dark of night and almost unthinkingly fired at a moving object. Looking through the sights of a gun is an act usually accomplished by squinting, or by shutting one eye; performing that one-eyed act, Ned may or may not have hit the cat which later shows up at old Mr. Scully's house, missing an eye.

The cat, which may or may not have lost its eye as a result of Ned's act, suffers from single vision - it does not see whole: "As it peered toward the house, it shook its head constantly as though to clear away something that made seeing difficult" (66). In this way, the cat is like Ned himself, as he is in the earlier chapters of the novel. In these chapters we see the world through Ned's eyes, and what we see seems to be curiously one-sided-in effect, one-eyed.

The world as Ned imagines it and as Fox describes it for us through his eyes is bleak and unsettlingly suffocating, unsettling particularly because Ned usually understands the suffocation to be comforting rather than frightening. Images and ideas of age, illness, decay, emptiness and silence recur, particularly in terms of houses. There is the Brewster house, which "was old and narrow and leaned slightly" (13), and another "tall stone house whose windows were always shuttered . . empty for many years" (17). There is the Makepeace mansion, through whose windows can be seen "shadowy rooms where light barely penetrated" (17), and Mr. Skully's house, which "was very old and hadn't been much to start with; the floors creaked, and the window frames were nearly rotted away" $(60)$. Many of these houses are empty, the rest in varying stages of decay. Ned's own "big, ailing old house" (3) is filled with remnants of a dead past, with old National Geographics and "a box with a thousand old buttons and huge old trunks and boxes" and "piles of books and magazines and broken furniture" (29). As well as being old and decayed, Ned's world is silent. His house is "often silent" (25), and when he eats breakfast with his father, "The only noise had been their spoons hitting the sides of the cereal boxes" (45). Not inappropriately, there is a monastery next door.

Rather than the innocent, hopeful and forward-looking world we expect of childhood, then, this is something like a waste-land - a setting that we might read as an image of the end of time, not of youthful beginnings. Yet there is little sense that Ned, a child and therefore presumably at odds with age and decay and silence, is uncomfortable with his environment. He loves the rutted driveway his father complains about, the old tree his father wants to prune. He is so used to the silence of his life that when he visits the houses of other children he is "astonished at the great noise and thundering in the house, at his friend shouting 'Mom!' and banging doors and slamming windows and thumping up and down stairs" (32). And it is the noisiness of the housekeeper Mrs. Scallop that sums up Ned's annoyance with her: "That quietness had been shattered by the coming of Mrs. Scallop, whose voice now intruded in the dining room every morning, as sharp and grinding as the woodcutter's saw" (5). Throughout the novel, Ned's only contact with other children is on short walks home from school; he spends his time with and devotes his thought to those who are either old or sick and almost always silent.

Or else he is alone. Through the debris of the past that fills his home Ned walks at night, alone, feeling "as if he were the only person awake in all the great empty night" (29). He seems to rejoice in being king of all he surveys, king of darkness and emptiness and decay. For him this is home-not a wasteland, but a place of comfort, and he is less suffocated than comforted by it.

In fact, Ned actively seeks the security of enclosed spaces. As a storm rages outside, his mother suggests that "it cc.1ld be wonderful to be out on such a night, right in the middle of all that noise and rain, not crouching inside a stuffy room like scared mice" (79); but Ned "never felt so safe as he did, sitting with his mother and father, during such a storm" (79). Ned also sees the aged Mr. Scully as comforted by the constraint of his small house: "small and old and a bit decrepit, but it had fit so nicely around him, like a shell around a snail" (160). But interestingly, Ned also worries about old Mr. Scully in terms of the same image his mother used for herself, imagining him moving inside his house "like a mouse in a paper sack" (58). In fact, Mr. Scully most often figures in Ned's thoughts as not being protected enough. He feels sad as "he imagined the small old man lying beneath the thin blankets Ned had often made up his bed with" (103); shortly after, Ned himself thinks of blankets as an escape from disturbing thoughts about his responsibility to the cat: "It was a cold morning, and he wished he could get back into the warm bed, into the nest of his own warmth" (102); and he worries about Mr. Scully being alone, "especially at night when he felt the life of his own home gathered around him like a warm blanket" (91).

In church, "A cloud of drowsiness dropped over Ned like a cloth" (4); that cloud, like the comforting blankets he thinks of so often, seems to sum up Ned's view of his life - a safe, silent place whose constraints keep pain out. But Ned thinks of cloth again when he kisses his mother: "He'd. . kiss her cheek that was as soft as the flannel of his oldest pajamas. There was something clothlike about her skin. It made him sad for a moment though he didn't know why" (31). That sadness implies some glimmering of discomfort with the limitations of that which gives him comfort - of something that all the cloths and blankets are holding in and suffocating. As church ends, and another boy performs the childishly exuberant act of making a face, "Ned felt a great single shout of laughter rising inside of himself' (12)-one he holds back, keeps under the blanket of his calm surface. Yet when his father later laughs at the same situation, "Ned was at once reminded of the past, the time before his mother became ill. He imagined the three of them dancing down the living room holding hands, or skipping stones down by the Hudson River. . . . He knew it couldn't have been like that, he knew it must have rained or stormed, 
that they hadn't spent all their time dancing and skipping stones and laughing together, yet it felt as though they had" (13). This nostalgic dream of a lost Eden, a happier place preceding the presumed comfort of his life as it is, shows that Ned's apparent acceptance of his life is to some degree an act of self-delusion - a willed blindness.

The Eden Ned imagines is the world as it was before his mother became ill; and the central dissatisfaction of Ned's life is that illness, which is, paradoxically, the thing which causes its isolating comforts. Ned knows that the resident spirit of the "big, ailing house," that which creates the need for silence and sustains the bleak atmosphere of stillness and decay, is his mother's severe arthritis. So he must question his comfort with that which is so painful for her; he must think about the possibility that his acceptance of things as they are means his acceptance of her pain. On the other hand, his glimmerings of unhappiness with things as they are, his sense of being suffocated, might also be a source of guilt; Ned overhears his mother once saying to his father, "II can't bear all that goodness! Try to understand me. When someone is as helpless as I am, that goodness is like being drowned....' He'd puzzled over her words, wondering if what she meant was something like what he felt when Papa spoke in his preaching voice to him about someone being poor or afflicted or miserable" (26). Feeling suffocated by goodness implies that one is not good oneself.

In a simpler novel, Ned would feel suffocated and rightly wish an escape; in another sort of simpler novel, he would love the eccentricity of his family's life, see it as a sign of value to be eccentric. But the first few chapters of Fox's novel describe a more subtle situation. Ned either hates his unchildlike childhood and lies to himself about its comforts, or else, he actually does like it, but worries about the implications of his doing so. In either case, there is something unresolved here. Perhaps more than anything, it is something not understood, and as it eventually turns out, Ned will neither escape suffocation nor accommodate himself to it; he will merely come to understand the contradictory feelings he has been experiencing-develop insight into them. Meanwhile, all we know for sure is that Ned's life is strange, that it seems to suit him, but that there is a current of dissatisfaction running under the surface.

That dissatisfaction surfaces when Ned's Uncle Hilary arrives, bringing into the house what he identifies as the "hurly-burly of the city" as opposed to "an atmosphere of such meditative silence" (24). As Ned's mother says, "He brings us the world, doesn't he?" (39). While something like "the man without a country" in the novel Ned has daydreamed about in church (4), Uncle Hilary is a traveler who has chosen his homelessness; he personifies the romance and adventure of the world outside, usually represented in Ned's house only by the yellowing pages of old National Geographics and by the exotic gifts Hilary has previously given Ned. Ned's mother says, "Hilary, you change the day" (23), and Hilary does just that; he offers Ned a trip that would be a way out of his home's changelessness - something Ned has not actually yet realized he wants - and he brings with him the gun that leads Ned to shatter the walls of his comfortable life.

Ned once asked his mother, "What's outside of everything?" (30). Ned himself is clearly inside, surrounded by the comforting but possibly suffocating blanket of his life. It is the gun that drives him outside, both literally and figuratively - outside of the house, outside of his childhood, and also outside of the "goodness" of his father. Shooting it - making a noise-requires him to leave the house lest he break its silence (and thus call attention to himself, as he would have earlier had he laughted at church). Once outside the house, he sees it as a scary presence: "he glanced back at the house. Its shadow, enormous, black, nearly shapeless, lay on the ground" (44). And intriguingly, it is a similar shadow (seen through one eye) that causes him to shoot: "As he blinked and opened his right eye wide, he saw a dark shadow against the stones.... Before he could think, his finger had pressed the trigger" (45). The repeated shadows make it seem almost as if Ned has shot at the house itself, and all it represents, in an explosion that breaks its silence. The shooting is certainly an act of defying his father, who had told Ned to "turn his mind away" (41) from the gun, that is, to stifle the urge to use it. In giving in to it, in letting the idea into his mind and then acting on it, Ned has committed the enormous act of stepping beyond the bounds of parental authority. That this is in some ways a sexual release, a freeing of emotion and a declaration of independent manhood, becomes clear afterward: "He felt the gun hanging loosely at his side. He'd lost all interest in it" (46). The act of shooting the gun then separates Ned from his home, from his father's values, and from his childhood. He does turn his mind away, not from the gun, but from his family - and his doing so makes him realize how much he has felt suffocated by what earlier seemed only to give him comfort.

Such an event might be interpreted in different ways - as a statement of one's independent authority or as a childish act of giving in to irresponsible urges. At first the novel seems to suggest that it is the latter: Uncle Hilary has implied that the gun itself is a childish object when he says, "It's time you had a boy's present instead of an old bone or a dead bug" (36), and when Mr. Scully sees the one-eyed cat, he suggests that "someone used him for target practice. A boy would do that" (66); and the immature boyishness of an interest in guns is confirmed when the neighbor boy with whom Ned walks home "made two guns with his index fingers. 'Boom! Boom! That's what l'd do to itty-bitty kitties!' he shouted" (82).

The pages that follow the shooting incident reinforce the idea that Ned's act was wrong. "The gun was like a splinter in his mind" (90). Before he felt comfort, and denied feelings of suffocation; now, having admitted to those feelings, he has lost the comfort. And he may no longer be one-eyed, for he sees far more, and far differently: "He remembered a fairy tale Mama had read him about two children who had gotten bits of glass in their eyes, and how the glass had changed their vision of everything" (101). Ned's act of looking through the glass of the gunsight has had the same effect on him as it had on Kay, one of those two children in Andersen's "Snow Queen." It has awakened him to consciousness of things he had not been able to see (or admit to being able to see) before.

One thing he sees differently is his home: "He looked up at the house. For a moment, he felt it was closed against him" (89). He sees himself separate from his family as well as from the house, as he embarks on a series of lies in order not to have to speak about the cat and the blame he feels for its plight. As a result, Ned thinks, "It was as if he'd moved away, not to the parsonage next to the church, or to Waterville, but a thousand miles away from home. What did matter was that he had a strange new life his parents knew nothing about and one that he must continue to keep hidden from them" (117).

Paradoxically, then, Ned's move outside the comforting constraint of his parent's support is itself constraining. As Ned's 
mother says, "A person shouldn't have to tell everything, but sometimes a thing gets in the way of a person's life" (154). The lies Ned tells are such a thing, a constraint: "A lie was so tidy, like a small box you could make with nails and thin pieces of wood and glue. But the truth lay sprawled all over the place like the mess up in the attic" (54). Such messes are like life itself untidy collections of events and objects that can be placed in boxes only when their real usefulness is over, like the contents of the messy boxes of Ned's attic, or of the boxes that Ned helps Mr. Scully to put in order; not incidentally, the order in a life's remnants can be created only after they are no longer neededand the greatest order is achieved when they are all thrown away.

On the same page as the one on which we hear that truth is like the mess in the attic, we hear of Emily Kimball, "whose shoelaces were often untied and whose hair never looked combed" (54). Emily lives in a "big, ramshackle house" (57) surrounded by the mess of a large family; and in their free and easy lack of order, or boxing in, the Kimballs contrast with the intrusive Mrs. Scallop, who claims to wear her heart on her sleeve, but is nevertheless "insulted several times a day" (16) by the world not being what she insists it is, and whose imperious need for control forces her to live a life boxed in from the world. Ned's mother says, "You must beware of people who wear their hearts on their sleeves; it's not the natural place to keep your heart - it turns rusty and thin, and it leaves you hollow inside" (72)-like an empty box, a lie that has squeezed the truth out and thus created a perfect order - and a perfect emptiness. Ned finally realizes the danger of such a constraining lack of contact: "She was a person to whom nothing, he thought, could ever be explained. She was locked inside of her own opinions like a prisoner" (200-201) - as her name suggests, like a scallop in a shell. And the imprisoned being, he realizes, is afraid of him - has created the prison to protect herself. A parallel prison is the stroke that still deadens Mr. Scully's body; Ned wonders, "Did something inside him run about - trying to find a way out?" (181). This image suggests how far Ned has moved from his conviction that Mr. Scully is safe like a snail in the shell of his house.

At one point, we are told that "Ned loved snow" (119) - it is like the blankets he has earlier associated with comfort, that which keeps away intrusive noises: "The heavy fall of snow muffled all sound; it made a kind of soft roaring" (167) which makes Ned think of being inside a seashell-like Mr. Scully in the shell of his house (and perhaps like Mrs. Scallop in the shell of her self?). He must realize that the muffling of snow can be deadening, as he does when he describes a "snow-covered landscape": "In other seasons of the year, something moved or fluttered or flew past, leaves, birds, insects, squirrels - the meadows waving like banners in a breeze-but now nothing moved that Ned could see" (164). Not surprisingly, then, as Ned worries over the fate of the one-eyed cat, his constraining lies become uncomfortable like snow: "All the lies he had told, the subterfuge, were piled up over the gun like a mountain of hard-packed snow" (162).

For Ned, the snow melts. He is able to speak the truth, and, perhaps more significantly, to hear his parents speak truths that tell him he is not really different from them or alone. Yet paradoxically, what he is not alone in turns out to be his aloneness - his inevitable separation from others; it's no accident that there is no other person who actively works to help Ned thaw, as Gerda helps Kay in "The Snow Queen." Ned learns that his mother too has cravings for separateness - that she once ran away for some months when he was young because she too felt suffocated by his father's goodness; to be with other people always requires some isolation from them, some shellmaking or blanket-covering, some desire for a private space away from them. Just as significantly, Ned's father lets him know that a lie he thought private was actually shared - that his theft of a communion glass as a young child was known but that the knowledge was not acted upon, thus creating a peculiar form of communion that allows the privacy of those who commune. His mother too has given him the space in which to lie and protect himself, for she tells him she looked through a window and saw him with the gun on the night of the shooting, but said nothing. Ironically, then, the source of Ned's torture, his separation from his family, has been a gift from his parents - and his knowledge of that is finally what allows him to return to them. He comes to understand that his separating guilt, while genuinely an independence, was so only because it was allowed; he was given the space in which to be independent by those who controlled him, and returns to a family which can be together because it allows such isolation.

Ned's guilt has led him to a growing maturity as well as growing insight. The boyish act of defiance and the guilt that followed it led to the responsibility he felt, first for the cat, then for Mr. Scully. Paradoxically, again, the act of separation has tied him to the world, and to other people.

As Ned and his mother return home at the end of the book, he feels as if the Makepeace house (the appropriateness of its name now apparent, for his mother has found a way of making peace with him there) is "another country." It is a just substitute for the more romantic exiles he once imagined, for its empty loneliness points out, as he says, "the comfort of his own house behind him" (214)-it is an empty shell, like Mrs. Scallop. He can now accept the comparative comfort of home by acknowledging its discomforts - that the comfort emerges to some degree from his father's suffocating "goodness," but also that the house houses his mother's pain, a disquieting discomfort that cannot ever be kept outside. Ned realizes that his house and his own family are the location of the inevitably paradoxical confusion of security and suffocation, separation and communion, pain and love.

Ned becomes conscious of some of these confusions as he tells his mother about Mrs. Scallop's foolish story that his own birth led to her illness: "He knew his mother hadn't gotten sick because of his birth - perhaps there was an inchworm of doubt stirring in his mind because of Mrs. Scallop's words, but that was all. He knew what he'd done, he'd pulled a false reason down like a window shade to hide the real reason he was unhappy these days" (96). Like a window shade, that "false reason" separates Ned from others, prevents them from seeing in to him, and him from seeing out to them. Later, when Ned sees Mr. Scully's house as lifeless, he "looked up at Mr. Scully's windows. The shades were drawn" (103); and later still, "Mr. Scully's shades were drawn; the house had a pinched look as though it felt the cold" (120). In One-Eyed Cat, a novel in which seeing is the source of insight, windows and the shades that block them are a central image. Windows and doorways are the ways into and out of private spaces; and people look through them again and again throughout the novel. ${ }^{1}$

Looking through glass can be an act of violence-as when Ned got the cat in his sights; ironically, he has been told he has "a true eye" (38). On the other hand, glass can allow clear vision: as he tells Mr. Scully of the shooting, Ned imagines the 
scene of his crime "all magnified in this instant as though his memory had become a microscope directed toward that moment when he'd held the Daisy" (187) - a repetition of seeing clearly through a gunsight, but one that allows clarification and understanding. Like gunsights, windows allow one to see the dangerous world outside clearly, yet to be at a safe distance from it. The first thing we hear of Ned's house is that "from its windows there was a view of the Hudson River" (2). Ned's mother looks out those windows almost every time she appears in the novel. Her illness means that she is closed off from the rest of humanity, except for her window; her situation sums up the human condition as Ned eventually comes to understand it.

Towards the end of the novel, Ned's mother seems to be on the way towards a cure: "It was as if she'd flung herself right in to the middle of the parade and wasn't a watcher anymore. It frightened him a little" (198). It frightens Ned because for him as for his mother, being alone and looking out of windows is a safe way of approaching existence. On his solitary midnight trips through the dark house, Ned goes from window to window looking out and feeling safe; at one point, he sits at a window and watches "the lights twinkle across the river, glad to be away from the pain and craziness of grownups" (135).

Nevertheless, it is the act of looking out that leads Ned back into contact with others. He first sees the one-eyed cat in $\mathrm{Mr}$. Scully's yard "as he looked through the window" (65); and we are told again and again that either Ned or Mr. Scully or both of them watch the cat through the window $(105,106,125,135,139)$. $\mathrm{Mr}$. Scully also says that the cat "stares at the window . . looking to see if I'm up" (107); the window goes both waysit allows contact from a distance that also offers protection. The window allows the cat to be an object of concern and to be helped, but still to be alone - and as Mr. Scully also says, "It's funny how alone an animal can be . . . and still be all right" (108). He speaks for all animals, including the human ones.

The cat looks in through the window to see Mr. Scully and Ned; Ned looks through the door of his mother's room, and feels like an intruder (10). He also peeks in at her later, and sees that, perhaps symbolically, "darkness was filling the windows" (26); he sees her as he believes he should not, cut off from the world in a private solitude. At another point, he looks in on Mrs. Scallop in her room, and assumes that she is looking out - eavesdropping (24-5); and he also looks "through the screen" at Mr. Scully in his kitchen - a place separated from the world outside, where it was dark because "there was one window and it was dirty" (59). In all these instances, looks into private spaces are acts of intrusion, but also, as Ned has not yet learned, moments of contact with others in need of escape from their isolation.

The place that best evokes the isolation of private places one is not supposed to look into is the Makepeace house. Ned "looked through the dusty windows at shadowy rooms where light barely penetrated" (17), and sees a place dead and dark, cut off from life; and his mother echoes this action at the end of the book, as she peers through "a huge dark window" of the mansion, sees nothing, and concludes, "Nobody there... We must all part, Ned" (209-10). As he avoids his feelings of guilt over the cat, Ned actually imagines himself escaping to another similarly empty old house, where he would "open a window and climb in and wander through the rooms" (85)-just as he wanders through the rooms of his own old house feeling pleasantly isolated. At the height of his feeling of separation from his family, Ned stands outside, and "then he saw the lights shining through the windows of his home" (130). He imagines his parents happy inside, without him; but then, "He glances through the bay windows of the living room" (131) and discovers that "the room was empty" (131) - as chillingly void viewed from the outside as the Makepeace house is. A similar feeling of isolation cornes when Ned stands outside again, and "as he looked up at the stained-glass window on the staircase landing, he knew he's never been quite so miserable in his life" (139) - a feeling only mildly diluted by seeing Mrs. Scallop. "through the kitchen window" seeming to be conducting an orchestra (139).

Seeing Mrs. Scallop in that way is another act of intrusion, a looking in on a private moment which this time gives Ned a sense of comfort, of contact with others. Interestingly, the solution to Ned's anguished sense of being separated from everybody else comes through moments when he believes his own privacy has been observed, especially by other people looking through windows. Ned even understands his sense of Mrs. Scallop's intrusiveness as a matter of her looking at him: "Mrs. Scallop was a person who could interfere with you by just glancing in your direction" (170). Earlier, Ned remembered visiting an asylum with his father: "he'd looked up once and thought he'd seen a round pale face gazing down at him like a small moon" (42); and he has felt the same sense of being observed from a window (perhaps the same attic window he himself had secretly observed the world from) as he returned to the house after shooting the gun: "he was sure there was a face there, pressed against the glass, looking down at him the way the person looked at him through the heavy black wire screen of the asylum years before" (46). It is his concern about this face, the knowledge that his act was not unobserved, that he is not really separate and disconnected, that has caused Ned's guilt: "Had he really seen a face that night looking down at him from a window in the house?" (51). Later, he approaches the house throwing stones, feeling a similar guilt and "hoping Papa wasn't looking out of a window and seeing what he was doing" (110). And when he tries to escape his guilt by fleeing to the porch of the Makepeace house, "if he looked north, he could, if the sun was out, catch the glint of an attic window in his own house" (168). It is as if the windows of the house and the idea they evoke of being observed intrude upon his escape from it.

But such escapes are dangerous - avoidance of contact with others, attempts to hide under blankets. Windows prevent such escapes. During the storm, as the family sit in their safe house, "a flash of blue-white light came through the window at the landing" (78). Indeed, the glass of windows is fragile, and therefore dangerous - it turns a comfortable house into a potentially invadable space, as Ned imagines his own house is as a result of his mother's illness: "It almost seemed as though, overnight, they'd moved into another house in another part of the world, a house whose walls and floors were made of glass that might, if Ned wasn't very careful, shatter" (25-6). But invasions are not always destructive - the right kind, the kind which involves looking in from a compassionate distance rather than breaking in, might be like light, which passes through window-glass without shattering it. The same landing windows through which Ned sees frightening lightning are the place "through which the sun poured" (21); and the windows of Momma's room, which can be filled with darkness (26), can also be "golden with sun" (21). So, even, can Mrs. Scallop's 
kitchen: "It was always dark in there except for a brief moment in the late afternoon when a ray of sunlight entered the kitchen window and lay like a cloth of gold across the worn oilcloth of the kitchen table" (74). Light comes through windows; the world enters in, no matter how hard one tries to keep it out, and the invasions one fears often create warmth and light as well as pain.

The essential message of One-Eyed Cat, the idea of distance as a source of love, is summed up by the images of watching and of being watched. Through a doorway, Ned's father saw him use the communion glass he once stole as a young child-but said nothing; ${ }^{2}$ his mother saw him with the gun through the window-but said nothing. We each live in a private space; the spaces have doors and windows. We can pull the shades and lock the doors, and live alone; we can intrude through others' doors and windows. But if we are wise, we will not intrude, and we will pull up the shades and let the light shine in; we will watch others through windows, as Ned's parents watch him and as Ned watches the cat, lovingly and hopefully, but without intruding. As Mr. Scully says, "I learned how nice it is to watch an animal instead of pouncing on it and hugging it every minute, covering up its nature with your own" (86). Similarly nice, but equally difficult, is to acknowledge that one is being watched, that people stand at windows and see out - as Ned's parents have seen him do wrong, yet given him the freedom to resolve the problem himself, and as Mr. Scully "seemed to be looking straight into the center of him" (186) as Ned tries to tell him about shooting the cat, and yet allows Ned his guilt.

One-Eyed Cat is a celebration of life that celebrates distance. With unassuming subtlety, it brilliantly reveals that what we see from a distance, while not close to us, is not all that separate from us either.

\section{NOTES}

1 Their doing so may be another reminiscence of "The Snow Queen," which often refers to windows. The intimacy between Gerda and Kay is first suggested by the fact that their houses are so close that "all you need do was step over the gutter and you would get from one window to the other" (231); the happy ease of the end is symbolized by the fact that "the roses in the gutter were thrusting their flowers in at the open window" (271). But in winter, the closed windows protect the children from the cold outside; Kay leaves the protection of his home when the Snow Queen stands outside his window and beckons. Later, Gerda's innocence allows her to enter the windows of the Snow Queen's palace, which are made not of sharp glass but of cutting winds. The house of the old woman who bewitches Gerda also has interesting windows, "very high up, and the panes were red, blue, and yellow - the daylight shone strangely inside through all those colours" (24), just as it does on the staircase in Ned's house in One-Eyed Cat: "On the landing floor there were pools of color, reflections from the stained glass window through which the sun poured" (21).

2It's clearly no accident, in the context of all these references to windows, that the object in question should be a glass; nor, given the implications Fox attaches to windows, that it should be a communion glass.

\section{WORKS CITED}

Andersen, Hans Christian. "The Snow Queen." Hans Andersen's Fairy Tales: A Selection. Oxford and New York: The World's Classics-Oxford University Press, 1959; rpr. 1984.

Fox, Paula. One-Eyed Cat. New York: Dell Yearling, 1985.

Perry Nodelman, a past president of ChLA is the author of Words About Pictures (Georgia) and The Pleasures of Children's Literature (Longman)

\section{Spirals of Consciousness: Rose Guy's "Friends" Trilogy}

\section{by Nancy Tillman Romalov}

Black women writers and critics have been recoding the language used to discuss the experience of growing up female in America. Critics Bell Hooks, Barbara Smith and Mary Helen Washington, for example, question whether white feminist discourse can be meaningfully applied to the lives of AfricanAmerican women. By focusing on the commonality of all women, these critics contend, white feminists ignore the particulars of oppression; they fail to account for the differences in the quality of life created by class and race. If feminist literary criticism is to incorporate the black voice, then, it must be prepared to see the politics of gender, race and class as interlocking factors in the writings of black women.

The impulse toward unity and homogeneity of experience, of which white feminists have been accused, also mars our work with children's and adolescent literature. The problem arises when we begin to theorize about the phenomenon of childhood. Calling upon the schema of Piaget, Erikson, Elkind and others, children's literature critics often ghettoize children into clearly delineated stages of cognitive and linguistic development, needs and interests. We talk about the "adolescent experience" or the "female experience," as though such experience were uniform across cultures and classes. In discussing the Young Adult novel, for instance, critics will focus on thematic consistencies of this "coming-of-age" genre: emerging sexuality, concepts of self-worth and identity; the search for love and acceptance by peers and the subsequent breaking away from family; or they will apply Erik Erikson's concept of "identity crisis" to describe the adolescent search for autonomy with little or no regard to how these concepts are embedded in the dominant white culture, reflecting that culture's values and history. Such perspectives on childhood are further reduced in credibility when the male adolescent experience is assumed to be the universal human pattern.

The need to broaden the definitions of the "adolescent experience" and the "adolescent novel" to include both a feminist and a black perspective comes into closer focus with the emergence of works by black women authors. Virginia Hamilton, Mildred Taylor, Joyce Carol Thomas, June Jordan, Sharon Bell Mathis, Eloise Greenfield or Rosa Guy, to name a 